\title{
Determination of whey proteins in different types of milk
}

\author{
Lenka Ruprichová1, Michaela Králová1, Ivana Borkovcová1 ${ }^{1}$ Lenka Vorlová1, \\ Iveta Bedáňová ${ }^{2}$
}

University of Veterinary and Pharmaceutical Sciences Brno, Faculty of Veterinary Hygiene and Ecology, ${ }^{1}$ Department of Milk Hygiene and Technology, ${ }^{2}$ Department of Veterinary Public Health, Animal Protection and Welfare, Brno, Czech Republic

Received June 6, 2013

Accepted December 4, 2013

\begin{abstract}
Protein analysis is very important both in terms of milk protein allergy, and of milk and dairy product adulteration ( $\beta$-lactoglobulin may be an important marker in the detection of milk adulteration). The aim of this study was to detect major whey proteins $\alpha$-lactalbumin and $\beta$-lactoglobulin and their genetic variants by reversed-phase high-performance liquid chromatography. Milk samples from cows $(n=40)$, goats $(n=40)$ and sheep $(n=40)$ were collected at two farms and milk bars in the Czech Republic from April to June 2010. The concentration of $\alpha$-lactalbumin was higher in goat's milk $\left(1.27 \pm 0.05 \mathrm{~g} \cdot \mathrm{l}^{-1}, P<0.001\right)$ and cow's milk $\left(1.16 \pm 0.02 \mathrm{~g} \cdot \mathrm{l}^{-1}, P=0.0037\right)$ compared to sheep's milk $\left(0.95 \pm 0.06 \mathrm{~g} \cdot \mathrm{l}^{-1}\right)$; however, concentration of $\alpha$-lactalbumin in goat's milk and cow's milk did not differ significantly $(P<0.05)$. Goat's milk contained less $\beta$-lactoglobulin $\left(3.07 \pm 0.08 \mathrm{~g} \cdot \mathrm{l}^{-1}\right)$ compared to cow's milk $\left(4.10 \pm 0.04 \mathrm{~g} \cdot 1^{-1}, P<0.001\right)$ or sheep's milk $\left(5.97 \pm 0.24 \mathrm{~g} \cdot 1^{-1}, P<0.001\right)$. A highly significant positive correlation $(\mathrm{r}=0.8686 ; P<0.001)$ was found between fraction $\mathrm{A}$ and $\mathrm{B}$ of $\beta$-lactoglobulin in sheep's milk, whereas in cow's milk there was a negative correlation $(\mathrm{r}=-0.3010 ; P=0.0296)$. This study summarizes actual information of the whey protein content in different types of milk which may be relevant in assessing their allergenic potential.
\end{abstract}

$\alpha$-lactalbumin, $\beta$-lactoglobulin, cow, goat, sheep, RP-HPLC

Major whey proteins $\alpha$-lactalbumin (LA) and $\beta$-lactoglobulin (LG) are strongly correlated with the nutritional value and the functional properties (i.e. gelling, filmforming, foaming and emulsifying) (Moatsou et al. 2005). However, lactoglubulins can also cause development of allergy to cow's milk, mainly affecting children (Monaci et al. 2006). The most allergenic whey protein is $\beta$-lactoglobulin, which constitutes $50 \%$ of whey proteins. Prevention of allergies to cow's milk is based on total elimination of cow's milk from a diet. Nevertheless, some studies (Skripak et al. 2008; Passalacqua et al. 2012) indicate that administration of gradually increasing doses of the allergen leads in children to induction of tolerance to the substance that originally caused the allergic reaction. It is therefore important, especially for people suffering from allergy to milk protein, to know the content of particular proteins in food (Monaci et al. 2006; Passalacqua et al. 2012). The content of whey proteins and identification of individual fractions are also important because of milk adulteration, especially in case of replacement of goat's or sheep's milk by cow's milk. The content of whey proteins differs in different milk types. In some cases, we can also identify the presence of different genetic variants which can help reveal adulteration (Veloso et al. 2002; Karoui and Baerdemaeker 2007). Genetic variants may influence the production of milk and its nutritional and technological properties (Formaggioni et al. 1999; Kuczyńska et al. 2012). In cow's milk, the most common genetic variant of $\alpha$-lactalbumin is the $B$ variant and the major genetic variant of $\beta$-lactoglobulin are A and B (Farrell et al. 2004). Whey proteins are used to indicate the method of 
heat treatment, which is important in connection with new technologies (ESL Milk Extended Shelf Life Milk).

The aim of this study was to determine the content of major whey proteins and identify their genetic variants in cow's, goat's and sheep's milk. The whey protein profile needs to be updated because of the reduction of dairy cattle number and changing breed profile.

\section{Materials and Methods}

\section{Samples}

A total of 120 samples of milk collected from cows, goats and sheep on two farms and eleven milk bars in the Czech Republic were analyzed. Cow's milk $(n=40)$ from Holstein and Czech Fleckvieh breeds were collected from eleven milk bars from April to June 2010. Goat's milk $(\mathrm{n}=40)$ was collected from White Shorthaired goats on a goat farm in the Southern Moravian Region of Czech Republic from May to June 2010. Samples $(n=40)$ of sheep's milk were collected from a sheep farm in the Zlín Region from May to June 2010. The sheep were mainly Lacaune $(87.5 \%)$, and the minor breeds were Improved Wallachian and East Friesian sheep. The samples were stored at $-18{ }^{\circ} \mathrm{C}$ until analysis.

\section{Sample preparation}

Prior to HPLC analysis the milk was thawed. Raw milk samples were defatted by centrifuging at 3,000 $\mathrm{g}$ for 15 min. The supernatant was precipitated by the addition of $10 \%$ acetic acid (Penta, Czech Republic) until reaching a pH of 4.6 (López-Fandiño et al. 1993) and filtered through a $0.22 \mu \mathrm{m}$-pore nylon filter into vials, and then analyzed.

Standards of $\alpha$-lactalbumin $(\geq 85 \%)$ and $\beta$-lactoglobulin $(\geq 90 \%)$ from bovine milk (Sigma Aldrich, USA) were weighed $(10 \mathrm{mg})$ and dissolved in mobile phase $\mathrm{A}$ in $10 \mathrm{ml}$ volumetric flasks.

\section{Validation and optimization of RP-HPLC}

Optimization of HPLC analysis was performed using standard solutions of $\alpha$-lactalbumin and $\beta$-lactoglobulin. Calibration curve for the $\alpha$-lactalbumin was designed over a concentration range of $0.404-1.571 \mathrm{mg} \cdot \mathrm{ml}^{-1}$ $\left(y=0.5835 x-0.215 ; R^{2}=0.989\right)$. Calibration curve for the $\beta$-lactoglobulin was designed over a concentration range of $0.406-1.133 \mathrm{mg} \cdot \mathrm{ml}^{-1}\left(\mathrm{y}=0.3635 \mathrm{x}+0.076 ; \mathrm{R}^{2}=0.9752\right)$. The method's sensitivity was detected using a slope of calibration line.

The repeatability of the procedure was determined from the results of multiple measurements per sample $(\mathrm{n}=7)$ and determined as RSD $2.53 \%$ for $\alpha$-lactalbumin and RSD $2.40 \%$ for $\beta$-lactoglobulin. The repeatability of retention times was determined from the results of multiple measurements per sample $(\mathrm{n}=12)$ and determined as RSD $1.02 \%$ for $\alpha$-lactalbumin and RSD $0.33 \%$ for $\beta$-lactoglobulin. The limit of detection was determined as $3 \mathrm{~S} / \mathrm{N}$ (signal/noise ratio) $0.0045 \mathrm{mg} \cdot \mathrm{ml}^{-1}$ for $\alpha$-lactalbumin and $\beta$-lactoglobulin. The limit of quantification (determined as $10 \mathrm{~S} / \mathrm{N}$ ) was $0.015 \mathrm{mg} \cdot \mathrm{ml}^{-1}$ for $\alpha$-lactalbumin and $\beta$-lactoglobulin. Evaluation was performed using an external standard and quantification was performed using timed groups (Ruprichová et al. 2011).

\section{RP-HPLC analysis}

Samples of milk were analyzed by reversed-phase high-performance liquid chromatography (RP-HPLC) and repeated $\times 2$ per sample. Separation of whey proteins was performed by liquid chromatograph Alliance 2695 with PDA 2996 detector (Waters, USA) and XBridge TM C18, $150 \times 3.0 \mathrm{~mm}, 3.5 \mu \mathrm{m}$ column (Waters, Ireland). Column temperature for whey protein detection was $40{ }^{\circ} \mathrm{C}$, run time was $35 \mathrm{~min}$. Injection volumes were $10 \mu \mathrm{l}$ for whey proteins. Mobile phase A consisted of water/acetonitrile (Merck, Germany)/trifluoroacetic acid (TFA) (Sigma Aldrich, USA) at a ratio of 95/5/0.1 (v/v/v) and mobile phase B contained water/acetonitrile/ TFA $(5 / 95 / 0.1, \mathrm{v} / \mathrm{v} / \mathrm{v})$. Gradient elution and mobile phase flow rate of $0.4 \mathrm{ml} \cdot \mathrm{min}^{-1}$ were applied. The detection was performed at $205 \mathrm{~nm}$.

Collection and evaluation of data were performed by the Empower 2 software (Waters, USA).

\section{Statistics}

Basic statistical characteristics (mean, standard deviation, maximum value, minimum value) were computed using Microsoft Excel. The results were analyzed using the statistical package Unistat 5.1. (Unistat Ltd., London, UK). For all variables tested in both experiments, normality was checked using a Shapiro-Wilk test (Zar 1999), and homogeneity of variances among groups was tested using a Bartlett-Box test (Zar 1999). Data were subjected to one-way ANOVA with the type of milk as the main effect with three levels (cow, goat, sheep), and subsequently to Tukey-HSD test (Zar 1999) for multiple comparisons to assess the significance of differences between all possible pairs of groups. To assess correlations in the study, Pearson's correlation coefficients between LG-A and LG-B were calculated. A $P$-value $<0.05$ was considered significant. 


\section{Results}

Table 1 shows the concentration of whey proteins and also the frequencies of individual $\beta$-lactoglobulin genetic variations in cow's and sheep's milk, which were revealed in the chromatogram (Figs 1,2). The concentrations of $\alpha$-lactalbumin were $1.27 \pm 0.05 \mathrm{~g} \cdot \mathrm{l}^{-1}$ in goat's milk, $1.16 \pm 0.02 \mathrm{~g} \cdot \mathrm{l}^{-1}$ in cow's milk, and $0.95 \pm 0.06 \mathrm{~g} \cdot \mathrm{l}^{-1}$ in sheep's milk. The highest content of $\beta$-lactoglobulin was found in sheep's milk at $5.97 \pm 0.24 \mathrm{~g} \cdot \mathrm{l}^{-1}$. The concentration of $\beta$-lactoglobulin was $3.07 \pm 0.08 \mathrm{~g} \cdot l^{-1}$ in goat's milk and $4.10 \pm 0.04 \mathrm{~g} \cdot \mathrm{l}^{-1}$ in cow's milk. Fig. 3 shows the profile of $\alpha$-lactalbumin and $\beta$-lactoglobulin depending on the concentration of different types of milk.
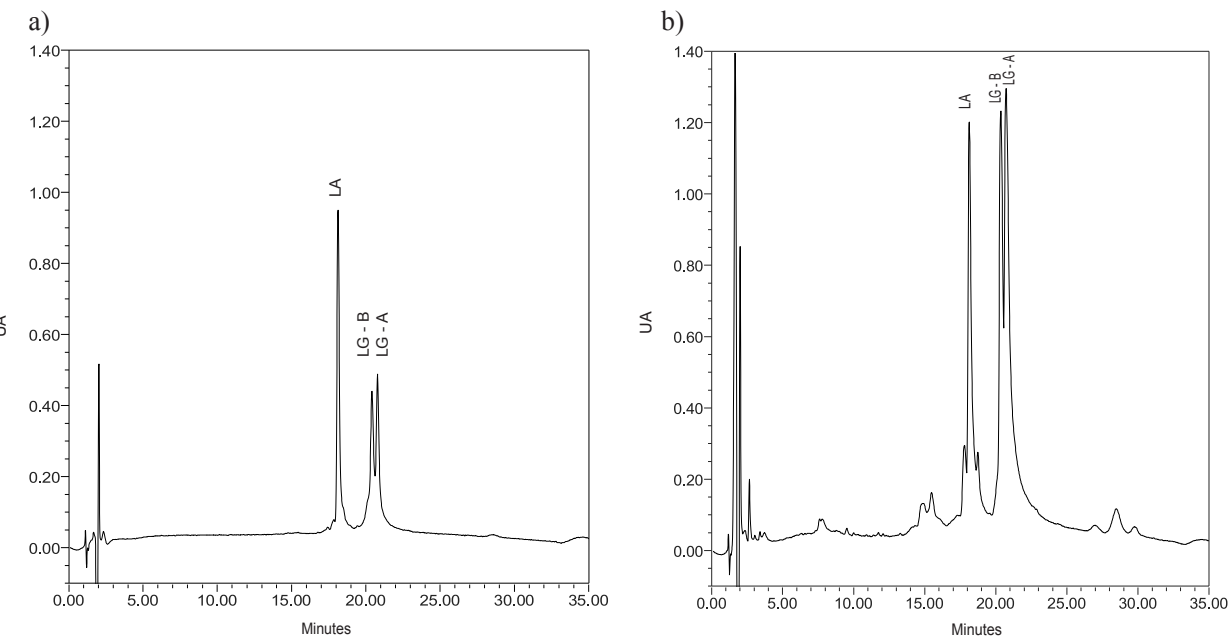

Fig. 1. Chromatogram of $\alpha$-lactalbumin (LA) and $\beta$-lactoglobulin (LG) of cow's milk

a) standard, b) samples

a)

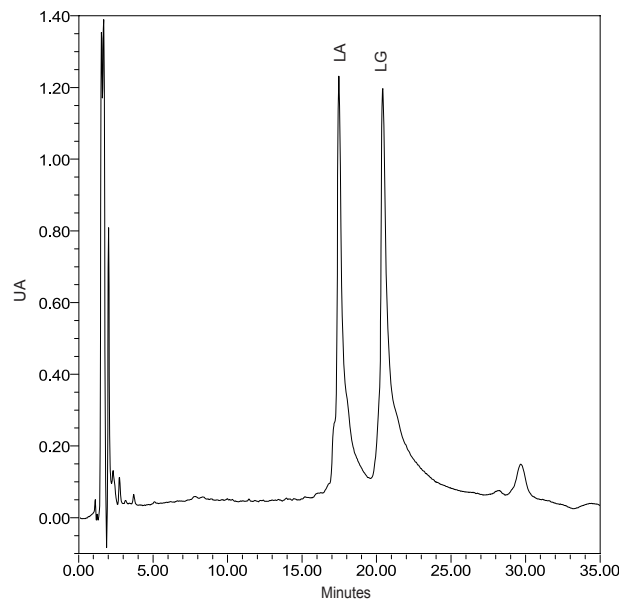

b)

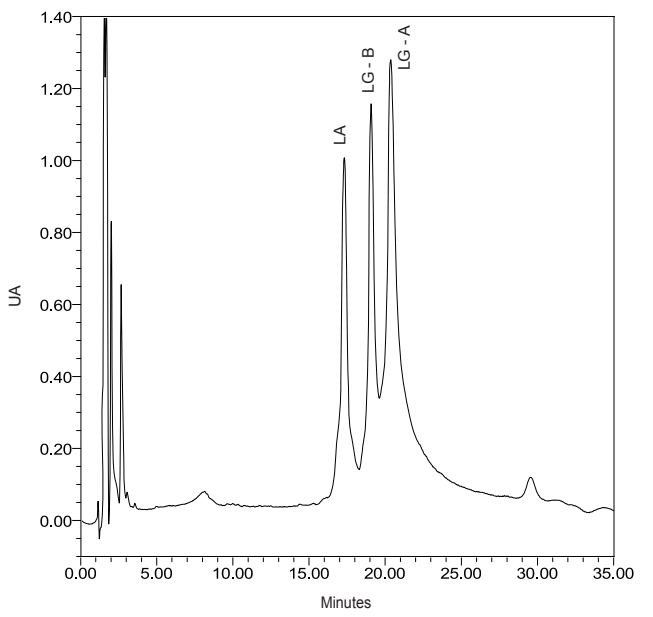

Fig. 2. Chromatogram of $\alpha$-lactalbumin (LA) and $\beta$-lactoglobulin (LG) in goat's milk (a) and in sheep's milk (b) 


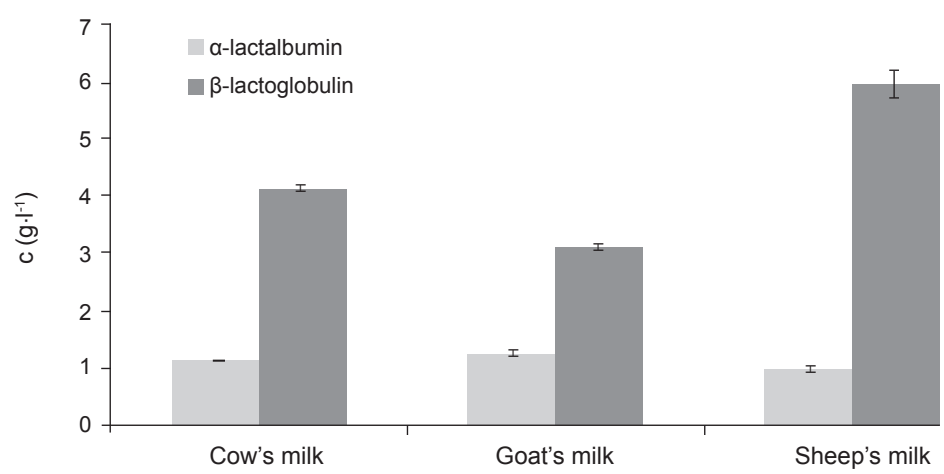

Fig. 3. Concentration (c) of $\alpha$-lactalbumin and $\beta$-lactoglobulin in different types of milk

Table 1. Concentration of whey proteins in different types of milk.

\begin{tabular}{lclllllllll}
\hline \multirow{2}{*}{$\left(\mathrm{g} \cdot \mathrm{l}^{-1}\right)$} & \multicolumn{4}{c}{ Cow's milk } & \multicolumn{4}{c}{ Goat's milk } & \multicolumn{3}{c}{ Sheep's milk } \\
\cline { 2 - 11 } & LA & LG-B & LG-A & LG* & LA & LG & LA & LG-B & LG-A & LG* \\
\hline Mean & 1.16 & 1.19 & 2.87 & 4.10 & 1.27 & 3.07 & 0.95 & 1.80 & 4.13 & 5.97 \\
Min & 0.99 & 1.03 & 2.45 & 3.61 & 0.65 & 1.74 & 0.44 & 0.95 & 2.36 & 3.43 \\
Max & 1.33 & 1.43 & 3.40 & 4.53 & 1.87 & 3.78 & 1.58 & 2.91 & 6.37 & 9.25 \\
SD & 0.10 & 0.11 & 0.26 & 0.25 & 0.34 & 0.49 & 0.38 & 0.55 & 1.00 & 1.54 \\
SEM & 0.02 & 0.02 & 0.04 & 0.04 & 0.05 & 0.08 & 0.06 & 0.09 & 0.16 & 0.24 \\
\hline
\end{tabular}

LA - $\alpha$-lactalbumin, LG-B - $\beta$-lactoglobulin-B, LG-A - $\beta$-lactoglobulin A, * LG was evaluation summarization of peaks LG-A and LG-B, SD - Standard deviation, SEM - Standard error of the mean

The LA content in goat's milk differed with a high significance $(P<0.001)$ from LA in sheep's milk. Similarly, LA in cow's milk differed with a high significance $(P=0.0037)$ from LA in sheep's milk. In contrast, the LA content in goat's milk did not differ significantly $(P<0.05)$ from LA in cow's milk. When evaluating LG concentrations, highly significant differences were found between goat's milk and sheep's milk $(P<0.001)$. Similarly, LG in cow's milk differed with a high significance $(P<0.001)$ from goat's milk. The difference between the LG content in goat's milk and sheep's milk was also highly significant $(P<0.001)$. Study of the dependence between the LG-A and LG-B content in sheep's milk revealed highly significant positive correlation $(\mathrm{r}=0.8686 ; P<0.001)$, whereas LG-A significantly negatively correlated $(\mathrm{r}=-0.3010 ; P=0.0296)$ with LG-B in cow's milk.

\section{Discussion}

The RP-HPLC method is suitable for determination of whey protein contents in cow's, goat's and sheep's milk and detection of their individual genetic variants. In previous studies, the content of $\alpha$-lactalbumin and $\beta$-lactoglobulin in cow's milk was the following:

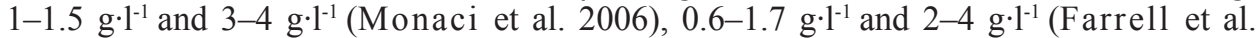
2004), respectively. Sztankóová (2006) detected $\alpha$-lactalbumin and $\beta$-lactoglobulin in cow's milk (1.05 g. $\cdot^{-1}$ and $\left.3.83 \mathrm{~g} \cdot l^{-1}\right)$, goat's milk $\left(1.31 \mathrm{~g} \cdot \mathrm{l}^{-1}\right.$ and $\left.3.33 \mathrm{~g} \cdot \mathrm{l}^{-1}\right)$ and sheep's milk $\left(1.16 \mathrm{~g} \cdot \mathrm{l}^{-1}\right.$ and $\left.6.58 \mathrm{~g} \cdot \mathrm{l}^{-1}\right)$, respectively. These values are comparable with data from our study. 
The contents and genetic variants of fractions of different types of milk are different. Three genetic variants of $\alpha$-lactalbumin $(\mathrm{A}, \mathrm{B}, \mathrm{C})$ and nine genetic variants of $\beta$-lactoglobulin (A, B, C, D, E, F, H, I, J) have been identified in cow's milk (Ng-Kwai-Hang 2003). Dziuba et al. (2010) and Formaggioni et al. (1999) reported that more variants $G$ and $\mathrm{W}$ of $\beta$-lactoglobulin were found. Variant B of $\alpha$-lactalbumin and variants $\mathrm{A}$ and $\mathrm{B}$ of $\beta$-lactoglobulin are major genetic variants (Farrell et al. 2004). Our results confirmed this fact.

Moioli et al. (1998) reported that $\alpha$-lactalbumin and $\beta$-lactoglobulin in goat's milk had protein variants A and B and their DNA polymorphisms do not exist. In our study, we found only one variant of $\beta$-lactoglobulin in goats of the White Shorthaired breed.

There are three protein variants of $\beta$-lactoglobulin in sheep's milk: A, B and C and the same DNA polymorphisms (Moioli et al. 1998). Our chromatogram of sheep's milk in $\beta$-lactoglobulin A and B revealed two peaks. Major part of sheep's milk samples in our study originated from the Lacaune breed, minor part came from Improved Wallachian and East Friesian sheep breeds. Amigo et al. (2000) stated in their work that in sheep of the Laucane breed, Improved Wallachian sheep and East Friesian sheep, A and B genetic variants were observed like in our study. Alpha-lactalbumin has two genetic variants (A and B) but DNA polymorphisms do not exist (Moioli et al. 1998). The $\alpha$-lactalbumin $B$ variant is rare and was identified only in some breeds (Amigo et al. 2000). In our study, we did not identify $\alpha$-lactalbumin B fraction in sheep of any breed tested (Laucane, Improved Wallachian and East Friesian).

\section{Acknowledgments}

This work was supported by IGA VFU Brno 72/2010/FVHE of the Czech Republic and by the Ministry of Education, Youth and Sports of the Czech Republic, Project No. 6215712402 "Veterinary Aspects of Food Safety and Quality".

\section{References}

Amigo L, Recio I, Ramos M 2000: Genetic polymorphism of ovine milk proteins: its influence on technological properties of milk - a review. Int Dairy J 10: 135-149

Dziuba J, Minkiewicz P, Darewicz M, Dziuba B 2010: Milk proteins. In: Nollet LML, Toldrá F (Ed.): Handbook of dairy foods analysis. CRC Press, USA, pp. 79-107

Farrell HM Jr., Jimenez-Flores R, Bleck GT, Brown EM, Butler JE, Creamer LK, Hicks CL, Hollar CM, NgKwai-Hang KF, Swaisgood HE 2004: Nomenclature of the proteins of cows' milk-sixth revision. J Dairy Sci 87: 1641-1674

Formaggioni P, Summer A, Malacarne M, Mariani P 1999: Milk protein polymorphism: Detection and diffusion of the genetic variants in Bos genus. Annali Facolta Medicina Veterinaria, Universita Parma 19: 127-165

Karoui R, Baerdemaeker JD 2007: A review of the analytical methods coupled with chemometric tools for the determination of the quality and identity of dairy products. Food Chem 102: 621-640

Kuczyńska B, Puppel K, Gołębiewski M, Kordyasz M, Grodzki H, Brzozowski P 2012: Comparison of fat and protein fractions of milk constituents in Montbeliarde and Polish Holstein-Friesian cows from one farm in Poland. Acta Vet Brno 81: 139-144

López-Fandiño R, Olano A, Corzo N, Ramos M 1993: Proteolysis during storage of UHT milk: differences between whole and skim milk. J Dairy Res 60: 339-347

Moatsou G, Hatzinaki A, Samolada M, Anifantakis E 2005: Major whey proteins in ovine and caprine acid wheys from indigenous greek breeds. Int Dairy J 15: 123-131

Moioli B, Pilla F, Tripaldi C 1998: Detection of milk protein genetic polymorphisms in order to improve dairy traits in sheep and goats: a review. Small Ruminant Res 27: 185-195

Monaci L, Tregoat V, van Hengel AJ, Anklam E 2006: Milk allergens, their characteristics and their detection in food: A review. Eur Food Res Technol 223: 149-179

Ng-Kwai-Hang KF 2003: Heterogeneity, fractionation and isolation. In: Roginski H, Fuquay JW, Fox PF: Encyclopedie of dairy science. Academic press, Amsterdam, pp. 1881-1894

Passalacqua G, Landi M, Pajno GB 2012: Oral desensitization for milk allergy in children: state of the art (in Czech). Curr Opin Allergy Clin Immunol/CS 9: 66-72

Ruprichová L, Dračková M, Borkovcová I, Vorlová L 2011: Allergenic proteins in sheep milk. Potravinárstvo 5: 396-398 
Skripak JM, Nash SD, Rowley H, Brereton NH, Oh S, Hamilton RG, Matsui EC, Burks AW, Wood RAA 2008: A randomized, double-blind, placebo-controlled study of milk oral immunotherapy for cow's milk allergy. J Allergy Clin Immun 122: 1154-1160

Sztankóová Z 2006: Specific variability of goat's milk (in Czech). Náš chov 4: 78-79

Veloso ACA, Teixeira N, Ferreira IMPLVO 2002: Separation and quantification of the major casein fractions by reverse-phase high-performance liquid chromatography and urea-polyacrylamide gel electrophoresis: Detection of milk adulterations. J Chromatogr A 967: 209-218

Zar JH 1999: Biostatistical analysis (4 ${ }^{\text {th }}$ Ed). Prentice Hall, Upper Saddle River, NJ, 662 